\title{
Report of the Annual Meeting
}

Rapports annuels de la Société historique du Canada

\section{Peasant Mobility and Freedom in Mediaeval England}

\section{J. A. Raftis}

Volume 44, numéro 1, 1965

URI : https://id.erudit.org/iderudit/300639ar

DOI : https://doi.org/10.7202/300639ar

Aller au sommaire du numéro

Éditeur(s)

The Canadian Historical Association/La Société historique du Canada

ISSN

0317-0594 (imprimé)

1712-9095 (numérique)

Découvrir la revue

Citer cet article

Raftis, J. A. (1965). Peasant Mobility and Freedom in Mediaeval England. Report of the Annual Meeting / Rapports annuels de la Société historique du Canada, 44(1), 117-130. https://doi.org/10.7202/300639ar 


\title{
PEASANT MOBILITY AND FREEDOM IN MEDIAEVAL ENGLAND
}

\author{
J. A. Raftis \\ Pontifical Institute of Mediaeval Studies
}

The dual terms "freedom" and "mobility" in the title are not meant to indicate the scope of this paper - which would be very ambitious indeed ! - but to represent the necessary point of departure in locating this area of research in mediaeval history.

For, to put the matter briefly, in the study of this as of so many other areas of mediaeval social and economic history, the question of freedom or liberty currently emerges as a problem of historiography, a paper curtain as it were, imposed by later centuries; whereas the notion of mobility may be taken as a measure of the growth of scientific methodology itself, of the tearing away of the paper curtain.

In no better way did the easy assurance of the nineteenth-century man that he had found the formula for civilizations manifest itself, than in his notion of liberty. And in the English-speaking world above all, the sanguine surge of industrial growth over the last half of the nineteenth century guaranteed that the writing of history should be cast in the mould of liberal capitalism. Social and economic studies of the Middle Ages were ill prepared to develop and maintain a historiographical independence in this situation. In contrast with the political historians who had an accredited discipline of constitutional history abetted by the growing market for national histories, or the feudallegal historians who might always be assured of some continuation of chivalry through the literary salons of western society, the few pretensions of mediaeval social and economic history to a place in the nineteenthcentury sun were withered by the hard light of classical economics. At least the mediaeval borough might have been thought to find a ready niche in nineteenth-century man's heart, but the study of the borough was prolonged for generations, as Sir Maurice Powicke had pointed out, ${ }^{1}$ by the search for its democratic origins. Even the guild, long so hopefully the ancestor of modern labour unions, was found to possess alien elements of monopoly, status, and price fixing, so that interest in this institution paled before the image of free enterprise. W. J. Ashley's ${ }^{2}$ abortive attempt to incorporate matter from canonical sources into the study of English economic history, well illustrates how indigestible mediaeval materials p. 66.

1 F. M. Powicke, Modern Historians and the Study of History, London, 1955,

2 W. J. Ashley, An Introduction to English Economic History and Theory, London, 1892, I, Chapter VI. 
had become by the close of the nineteenth century. Small wonder that the peasant, non-capitalist, and often indeed unfree in public law, should fail to attract the attention of the new scientific history of the nineteenth century.

On the other hand, mediaeval social and economic history could expect little from beyond the pale of classical economic thought. By the late nineteenth century the spiritual heirs to the romantic reaction of earlier decades found themselves more and more in an alien world, and in opposition to that world, as with their political counterparts, often find themselves with strange bedfellows. Karl Marx was an unlikely ally, despite his acute observation that the economists regard bourgeois institutions as natural and based on eternal laws, and feudal institutions as artificial. Thus there has been history, but there is no longer any! But the neo-scholastics would clutch at $R$. H. Tawney's interest in the economics of Thomas Aquinas often oblivious to the labour theory of economics involved, but especially to the purpose in the politics of Fabian socialism.

The vigour, productivity, and eminence of English historiography of the late nineteenth and early twentieth century was such that only since World War II have critics been able to probe effectively soft spots and lacunae such as areas of mediaeval social and economic history. That these soft spots were there, was recognized earlier, of course. For example, from the later 1920's and throughout the 1930's Marc Bloch criticized again and again the use of the term liberty by historians of mediaeval English society. ${ }^{3}$ But Bloch remained prophetic, and only in 1958 was H. M. Colvin of Oxford able to say : "There are, nevertheless, at least two cognate heresies to which mediaevalists have been prone. One is the traditional conception of a free peasant society gradually reduced to servitude by feudal pressure which has recently been under attack from more than one quarter. The other is the unconscious tendency to look at the mediaeval past from a monarchical point of view..." 4 Such critiques are now familiar, and have been expressed by American mediaevalists George C. Homans of Harvard, and John Mundy of Columbia, to name but two.

While this critique of the historiography of liberty, as with all such critiques, ${ }^{5}$ is more and more becoming the couch for the analysis of the twentieth-century historian, in itself the critique is non-directive or even

3 Some of Bloch's criticism is summarized in an article by the present writer, "Marc Bloch's Comparative Method and the Rural History of Mediaeval England", Mediaeval Studies, XXIV (1962), 349-68.

4 History, XLIII (June, 1958), p. 85.

5 There comes to mind studies of the term "middle ages", cf. C. S. Gordon, Medium Aevum and the Middle Ages, Oxford, 1925. A more recent example would be studies of the term "feudal", e.g. Robert Boutruche, Seigneurie et Féodalité, "Le premier âge des liens d'homme", Paris, 1959, Introduction. 
negative in so far as historical science is concerned. This is particularly true for study of the peasant. For, unlike the first and second estate, and further estates in late mediaeval and modern times, the peasantry by the very fact of their illiteracy had, in the words of Lynn White junior, no voice of their own in the written traditions of the west. Church and state had their chroniclers, feudal man had his troubadours, but the peasant, despite the efforts of well meaning outsiders like Langland or Chaucer, had his story told by others. Our notion of the peasantry is, therefore, peculiarly a construction of historiography.

The positive story of the growth of mediaeval history has been the discovery by one scientific discipline after another that the classical historical science ${ }^{6}$ had cut us off from mediaeval man as life, growth, development, change, mobility. One after one, every discipline in the whole arsenal of mediaeval studies has had to apologize for disturbing the static scene. The tone of the apologies are of course changing, from C. H. Haskins' mild remark in the foreword to his The Renaissance of the Twelfth Century ${ }^{7}$ that "modern research shows us the Middle Ages less dark and less static", to Robert L. Reynolds in Europe Emerges ${ }^{8}$ stating in his introduction: "also seek to correct the commonplace distortion in the view of Europe which sees it as for thirteen centuries or more to have been "manorial," "feudal," static," "backward." A person today is backward, feudal, static, mediaeval, who so designates all the centuries and patterns of society and economy..."

Since the static notion of history had more literal meaning for such earthy disciplines as social and economic history, it is in these very disciplines that recent scientific advances have brought the most startling discoveries of growth and change. One has the feeling these days that the larder of the classical economists is being raided by mediaevalists as

6 To trace this question would require reference to a historiography prior to the nineteenth century. For example, in a valuable recent historiographical study, History Sacred and Profane (Bampton Lectures, London, 1964), Alan Richardson points up the wide scope of the above-mentioned nineteenth-century approach: "Macaulay is the great exponent of the myth of progress, and every past age is condemned as falling short of the materialistic prosperity (for the bourgeoisie) of the nineteenth century... Lord Acton at the end of the century remained convinced of the universal validity of nineteenth-century moral standards, which he thought that the historian should apply in his work." (p. 108) But Richardson rightly couples the success of this historiography to the rationalist bias in the science of history that supported it. As he says of Hume's Enquiry Concerning Human Understanding: "Thus in one paragraph of the Enquiry we see the two basic theses of the rationalist doctrine of history: first, the doctrine of static human nature..., and second, the view that the method of history is fundamentally the method of the natural sciences... The pages of history, that is to say, constitute the historian's laboratory in which he studies the laws of human behaviour, which he then formulates. But the very next sentence indicates that the truth about human nature and behaviour has already been decided upon before the research began ..." (p. 102).

7 Harvard University Press, 1927.

8 Madison, 1961, p. VIII. 
he reads of the Turner frontier theory applied to pre-thirteenth-century Europe, ${ }^{9}$ of just price as market price, of the eleventh-century money economy, of thirteenth-century banking, ${ }^{10}$ of technological revolution in the twelfth century, ${ }^{11}$ of analysis based upon population, productivity, prices, and wages data that can compare the twelfth with nineteenthcentury agrarian Europe! 12 But there still remains the main body of mediaeval life, called variously villagers, serfdom, peasantry - that $90 \%$ of mediaeval men and women who were small people on the land - who have been unresponsive to these studies, and who as a consequence do not yet have a place as real living persons in mediaeval studies. It is not perhaps a question of serious concern that the nineteenth-century romantic interest in the peasantry may have disappeared, ${ }^{13}$ but it is worthy of note that scholars have not built on the work of a $\mathrm{H}$. S. Bennett or Eileen Power from the 1930's. One has only to look at the Oxford Histories of England to remark a relative decline in the status of the peasant in twentieth-century historiography against earlier generations of scholarship. ${ }^{14}$

Paradoxically, one of the reasons for the decline in the historiography of the peasant has been scientific scepticism, an uncertainty that was not typically nineteenth century. For example, Lipson in his Economic History of England states briskly: "We have now to trace the process by which a nation of free cultivators became gradually transformed into one of dependent serfs." But in his conclusions he hesitates : "... it would be unsafe to regard the manor as the prevailing type of estate from the earliest times, on the ground that some were in existence before the Norman Conquest." 15 Or, to take another example, Sir Frank Stenton states bluntly: "The central course of Old English social development may be described as the process by which a peasantry at first composed essentially of free men, acknowledging no lord below the king, gradually lost economic and personal independence." 16 But when he comes to look directly at the new organization, Stenton cautions: "The origin of private justice is one of the unsolved problems of Anglo-Saxon history." 17

9 E.g. A. R. Lewis, "The Closing of the Mediaeval Frontier, 1250-1350," Speculum, XXXIII (1958), 475-83.

10 Cf. publications of Raymond de Roover.

11 Cf. publications of Lynn White jr.

12 This material is most readily available now in B. H. Slicher Van Bath, The Agrarian History of Western Europe A.D. 500-1850, English translation, London, 1963.

13 Indeed the romantic revival of the nineteenth century very likely strengthened the static notion of the peasantry by idyllic presentation of the mediaeval villager.

14 One might cite in contrast the writings centering about F. Seebohm in the late nineteenth century.

15 Vol. I, The Middle Ages, 10th edition, London, 1949, p. 15.

16 Anglo-Saxon England, 2nd edition, London, 1950,p. 463.

17 Ibid., p. 485. 
In short, such scholars query the legal explanations ${ }^{18}$ for decline of the peasantry, but fall back upon the economic explanation.

On the other hand, the more specialized workers in economic history of the past generation have gradually come to realize that there was not necessarily an economic foundation for the increase of serfdom. In 1937 M. M. Postan ${ }^{19}$ first indicated the actual increase in individual property ownership by villagers over the twelfth century, combined with a decline in the size and importance of the lords' demesnes. Slicher Van Bath ${ }^{20}$ has pulled together more recent scholarship in order to demonstrate how in the thirteenth century there was a growth of productivity, with a combination of cereal prices and wages to favour the tenant; and from the early fourteenth century commutation of services introduced an element of flexibility for both lord and tenant. Despite the fact such scholarship now clearly indicates a long run rise in status of European peasantry over the twelfth and thirteenth centuries, English economic historians, Postan 21 included, fall back upon legal explanations for decline of the peasantry.

In all this, however, there is implicit the increasing recognition of the inadequacy of traditional historiography for the study of the ordinary person in the mediaeval social scene. Eileen Power put the point bluntly: "He (the historian) did not care to probe the obscure lives and activities of the great mass of humanity, upon whose slow toil was built up the prosperity of the world and who were the hidden foundation of the political and constitutional edifice reared by the famous men he praised." 22 Sir Maurice Powicke and Helen Cam discovered the community aspect of the village to be more vital than the questions of economic, legal, or policical historians: "I saw that Wotton was not a manor in which a single lord ruled over a number of villeins, but that it was a community, very like an English village even to-day, but a community united by common practices, within a feudal framework, and directed by a

18 One of the most substantial criticisms of these traditional legal notions is given by T. H. Aston, "The Origins of the Manor in England," Transactions of the Royal Historical Society, 5th Series, VIII (1958), pp. 59-83. While Aston is concerned with Anglo-Saxon scholarship, his criticism is equally applicable to the historians of common law. That is, there is an assumption that common law developments of the twelfth and thirteenth centuries were at the cost of village society. Cf. F. W. Maitland, Domesday Book and Beyond (Cambridge, 1897), pp. 50, 54, etc.; or Paul Vinogradoff, The Growth of the Manor (London, 1920), transition from Book II to Book III.

18 "The Chronology of Labour Services," Transactions of the Royal Historical Society, 4th Series, XX (1937), pp. 179-93. And see also by the same author, "Glastenbury Estates in the Twelfth Century," Economic History Review, 2nd Series, VI (1953), pp. 360-1.

20 The Agrarian History of Western Europe, op. cit.

21 See, for example, Postan's effort to explain village tenurial structure with reference to common law in Carte Nativorum, Northants Record Society, XX (1960), especially p. xlix ff.

22 "The Peasant Bodo," in Medieval People (Pelican Book, 1939), p. 13. 
manorial court." 23 "The sociological interest of these cases lies in the evidence they afford that in the life of a village where intermarriage went on so freely between freemen and villeins there can have been no class barriers along the line of legal freedom and legal serfdom." 24

George C. Homans of Harvard went beyond these scattered impressions of English historians, and took a bold new step by collecting material from a wide range of sources for his volume English Villagers of the Thirteenth Century. ${ }^{25}$ But Homans' purpose, as his concluding chapters most clearly indicate, was sociological rather than historical. He did not seek to penetrate the life of any particular village; he did not really introduce us to the person of the villager. And so the villager or peasant still lacks a voice. Can such a voice be found ? It may be suggested that a full dress social survey of the kind familiar to social sciences of the twentieth century seems to be the only remaining way to answer questions about this segment of mediaeval social history. But are the sources available for such a study?

There are only the two kinds of village records extant in which one might hope to find the volume of information demanded by a social survey, and these are the manorial account rolls, and the village court rolls. But in the former, the account roll, the individual is usually a cipher - as indeed he is in centralized accounts to-day - and the information turns almost solely upon the economic administration of the lord's demesne. ${ }^{26}$ The village court roll, on the other hand, deals with a great number of names, and with a wide variety of human relation such indeed as are handled to-day in a score of institutions. If further advances were to be made on the study of the average villager, these would be through the study of the court rolls or not at all.

The historical literature at hand does not encourage the study of the court rolls. Looking upon the court roll as an auxiliary to the manorial management to be seen on the account roll, historians of mediaeval England have called these "manorial courts" - although the Latin title is court of such and such a village - and the same historians have considered these courts to be instruments whereby the lord extracted services from his serfs and kept them in subjection. As a consequence, these records did not seem to be sufficiently meaningful in terms of human

23 "Observations on the English Freeholder in the Thirteenth Century," in Wirtschaft and Kultur: Festschrift zum 70, Geburtstag von Alfons Dopsch (Baden bei Wien, 1938), p. 388.

24 "Pedigrees of Villeins and Freemen in the Thirteenth Century," in Liberties and Communities in Medieval England (Cambridge, 1944), p. 134.

25 Cambridge, Mass., 1942.

26 Hence, of course, the tendency for economic historians to follow the lead of legal historians in social interpretation. At the same time it should be noted that $R$. $H$. Tawney's great study became more possible precisely because he eschewed the account roll approach. Cf. The Agrarian Problem in the Sixteenth Century (London, 1912), p. 76. 
history to warrant the effort required to work out a methology for thousands of documents with an immense variety in detail.

Nor does the experience of scholars offer the inducement required to initiate a massive approach. As early as the second volume of the Selden Society (1889), F. W. Maitland had brought up the question as to "how best to garner the great mass of information contained in the manorial rolls." To legal historians Maitland recommended "In the first place it would be well to pick out a few selected manors, to select them because they have unusually complete and continuous records, and then to print those records in full." 27 But Maitland was unable to adopt this "first" approach himself, and his compromise, to print selections from various rolls, has remained the main means of scholarly production for legal, social and economic historians. Indeed, over the past generation there has been a falling off even in the publishing of selections, ${ }^{28}$ to judge from the list of serial publications made available by the Royal Historical Society.

Preliminary questions to be asked of the court rolls need, therefore, to be quite clear and blunt, namely 1) either these villages were nonentities, or they had some real rights - if the latter, what were they ? 2) and secondly, either the lord had an immediate coercive control over the villagers, or these moved at their own volition, if the latter, how, and why?

To probe these questions a study has been made of twenty-five villages in the east midlands. These court rolls were known to be among the most detailed extant, they were available from the thirteenth century and in large numbers - some 1500 for the fourteenth and fifteenth centuries for this group of villages - although the greatest concentration was for about a dozen villages. The nature of this investigation will now be found described in a volume entitled Tenure and Mobility, Studies in the Social

27 Select Pleas in Manorial and Other Seignorial Courts, I, Selden Society, II (London, 1889), p. XI.

28 No doubt one reason for this falling off is the "negative" view received from selections. Cf. Eileen Power, "Peasant Life and Rural Conditions c. 1100 to c. 1500," Cambridge Medieval History, VII (1932), p. 740, for such a negative view of court roll evidence. In this, as in her other writings (and those of H.S. Bennett), Eileen Power falls back upon "Literature" for her social interpretation. But the importance of literature for the social and economic interpretation of the life of the peasant still awaits scientific investigation. Several fruitful lines for such investigation might be: 1) literature as the voice of a non-peasant; II) the unconcern of recent literary scholarship with social questions (ef. the criticism of Margaret Schlauch, English Mediaeval Literature and Its Social Foundations, Warsaw, 1956, passim); III) the meaning of the wide agreement of capitalist and Marxist historians upon the "exploitation" of the peasant.

The selective approach has also been encouraged by new disciplines, especially geography and archaeology, leading to a greater emphasis upon regional and local studies. For something of Marc Bloch's concern with this disintegration of social history, see my article, op. cit. 
History of the Mediaeval English Village. ${ }^{2 \theta}$ So here we shall merely note some basic points emerging from these studies.

First, with respect to tenure: it was surprising to find from the earliest records of the thirteenth century that customary tenure was a right by blood, to find in other words that customary tenants had a title to land thought by Maitland, and others since, to be found only on land of ancient demesne of the king. A stable tenure appropriate to their village life had developed, just' as there had developed a peculiar monastic tenure, or the military tenure of the knight.

In addition to the obligations contracted with his lord, this customary tenure of the villages was an intimate personal and social act in village life itself. Rights to land through blood, even in the intensively competitive period for land, remained even when a woman succeeded, or when she married an outsider; such rights remained even when the legitimate heir had been illegally outside the village and for long periods, or when the land had been illegally sublet.

Perhaps the most striking feature of customary tenure was the adequacy of this system of succession until the late fourteenth century. By the time of our extant court rolls in the late thirteenth century a system of inheritance was running so smoothly that questions of disputed right to customary lands rarely reached the manorial court to require attention by officials. Among a peasantry who were not particularly law-abiding, and who were often greedy for land, this uninterrupted history of inheritance can only be explained by very well-known and very wide laws of succession. Rights to customary land were so clearly seen that succession was usually automatic; and rights to succession were so well worked out among various degrees of blood relationship that the failure of certain family lines to provide heirs posed no legal difficulties. ${ }^{30}$

Once the villager was seen to have a true title to land, it was not surprising to discover a wide range of commercial force at work in the village. It is difficult to find what would in reality be described as an 1964

29 Toronto, Pontifical Institute of Mediaeval Studies, Studies and Texts 8,

30 Court records tell us that there were family laws; but the local court did not pass judgement upon the rationale of these laws. On the one hand the principle of premier individual right by blood emerges strongly as the kingpin of the local legal structure. But over against this is another principle of "group rights" - wife, daughter, son, brother, can present a variety of claims to maintenance. Beneath the administrative structure of the local court lay kinship connections to which the court deferred the tenure of customary land. Where administration of customary land was temporary, as with tenure by the widow or maintenance arrangements for various members of the family, the court roll frequently served as a record and we can see how some decisions were made. But the permanent pattern of rights in land was a matter of blood relationships which were recognized but not established by court records. For the disposition of chattels too, the last will and testament of the villager seemed to take the administration of mobile goods out of the local court. 
absolute prohibition to the traffic in customary or freehold by villagers, or to the conveyance of customary land by freemen. Freemen only obtained customary land through village laws, that is through a villager (by marriage) or at other times by special licence of the lord. Once willing thus to submit to village laws, the freeman's possibilities for customary tenure were considerable. In order to maintain personal responsibility for services any customary tenant must either let his land only for very short periods of a year or two, or allow his property to be conveyed through the courts for a life tenure to a lessee who assumed all responsibilities vis-a-vis the lord. Both the short term and the life tenure offered many opportunities for a brisk traffic in land. And finally, nothing stood in the way of the unfree villager's tenure of freehold, so long as the charter was presented for recognition by the lord or his official.

The great numbers and variety in village land tenure illustrated by the general survey of this matter indicate a "village economy" underlying that manorial economy better-known to the historian. Whereas the hidage assessment, with the virgate and other subdivisions, was the basis for the manorial economy of the villager, the key to the village economy proper seems to lie in very small, variable, and perhaps often irregular and enclosed units. How little we know about the existence of these small units from other sources is most easily seen by an effort to reconstruct the village, buildings, lots, and gardens, from a manorial survey or extent. Extents tell us practically nothing about the existence of these things, and yet we know that there were buildings, lots, and gardens !

But the question still remained to be answered. What was the real basis of order in the village, if not villeinage or serfdom in its traditional meaning ? Or, what was the power of coercion if not the will of the lord ? The answer to this type of question emerged in four different ways :

1) It was found that the officials of the village were answerable to the whole village as well as to the lord. Indeed these officials, as local villagers themselves, often had more reason to respect the will of their neighbours than that of a distant power. ${ }^{31}$

2) Byelaws did not come with the brave men of New England, nor are they traceable only to the late Middle Ages, as scholars like Professor Ault have argued, but they are to be found in the earliest court rolls of the thirteenth century. These byelaws describe the age old dynamics of customary law : the necessity for collective action in the village economy. The implementation of local law was of material concern to the whole village, so the whole village became involved. ${ }^{32}$

31 Tenure and Mobility, especially Chapter Four, Section I.

32 Ibid., Chapter Five. G. L. Haskins, Law and Authority in Early Massachusetts, N.Y., 1960, stresses the deliberate choice of village courts as against 
3) The key to the ordering of the village economy was not the enforced settlement of serfs on land, but the peasants' own desire for land. The peasants' life was therefore basically 'static' in the sense of being local because he wanted it so, because he wanted to exploit the opportunities available for him in the village. When the villagers decided to leave their farms, as happened in these villages from around 1400 , the lord could do nothing about it. Villagers first deserted before the problem of enclosure and the new economic spirit of the fifteenth and sixteenth century arose. ${ }^{33}$

4) The means of ordering village life, the coercion to be found, was that of ancient tribal and communal societies. Far from forcing the villager to remain at home, this law of coercion used ostracism or outlawry as the supreme local penalty. On the other hand, the legal position of the serf in his home village may be usefully described as that of a citizen. In the local court he was recognized to be a resident by birth (nativus), while the visitor form beyond, whether from near or afar, was an alien (extraneus). Social acceptance was the ultimate norm of belonging in the village : an acceptance controlled by the tithing system for natives, and governing outsiders by their ability to find pledges for residence. ${ }^{34}$

In the same study movements of villagers from the late fourteenth century were traced in detail. The sheer magnitude of these movements was often startling (a cumulative picture of 40 to 50 ), though not surprising in view of our knowledge of deserted villages from this time. The general economic rationale behind the movements could often be obtained : land, labour, apprenticeship, trade, etc. There was some movement to as far away as London. But on the whole the villagers did not go far, and could not seem to have cared less for the historians' problem of escaping lordship since they were as likely to move to another village of their traditional lord, if that village happened to be close at hand and opportunities were offered for land and employment.

Despite these dramatic movements in the fifteenth century, once we realized that mobility was basically economic and social rather than legal and coercive, the question arose as to whether there was more mobility or possibility of mobility in the fifteenth than in the thirteenth century. Some villages had nearly a score of people away with or without licence at the beginning of the fourteenth century. Since there was no cumulative account on the rolls of those away without licence, these data could not be made readily available for the earlier centuries, but indications suggested large numbers. And it was equally clear that

common law courts by the New England lawyers themselves, and as a consequence the need for further study of these courts in their English background.

33 Tenure and Mobility, Part III.

34 Ibid., Chapter Six, Section I. 
for many years more were received into the village, whether in some permanent way in tithing, or only as seasonal labour, than had left the village for any reason. There was, in short, a great deal of movement both in and out of the village. And this mobility leads by many roads to the villagers' life. Why did so many daughters of the villeins leave to marry in neighbouring villages? Can we find out anything of the background of those villagers who left to become clerics? Who was able to afford payment for the many servants who came into the village? There was in village mobility, then, a door opening upon the humanity of the villager in his family and community involvements, his economic drives, his social organization.

And so these investigations seem now to be approaching the questions asked by modern social anthropologists : is there not an intrinsic peasant culture with its own values, and requiring its own methodology for investigation? ${ }^{35}$ Have we not tacitly assumed peasants to be 'primitives', and therefore peasant culture was implicitly non-culture ? ${ }^{36}$ In short, is not our weakness in the study of the peasant part of the same inadequacy in our approach to the culture of underdeveloped people, to non-western cultures, ${ }^{37}$ etc. ?

This identification of the study of the peasant villager with welltried disciplines of modern scholarship has encouraged us to take the next step, the tedious task of detailed investigation of the mediaeval English village. For a first survey there has been chosen the very detailed court rolls of villages for a six-decade from the time these rolls became extant in the late thirteenth to the mid-fourteenth century. ${ }^{38}$ In order to have as much as possible a controlled picture of at least local mobility, the five adjacent Ramsey villages of Broughton, Upwood, Abbots Ripton, Wistow and Warboys were selected. The 20,805 entries available for these villages, and the 4,816 persons that may be identified, indicate the mass data available for the study of the mediaeval village.

These village court roll data readily block out into three broad areas in social and economic life, namely, main families, officials and

35 Cf. Robert Redfield, The Little Community and Peasant Society and Culture, Phoenix Book, 1960.

36 Cf. Francis L. K. Hsu, "Rethinking the Concept "Primitive", Current Anthropology, 5 (No. 3), 1964 pp. 169-78.

37 Cf. Margaret Mead, Male and Female, N.Y. (1949) : "But the anthropological approach is to go out into primitive societies without any too specific theories and ask instead open-ended exploratory questions." (p. 29) "So one escapes from the bondage of asking only the questions that are based on our own and other known civilizations." (p. 45)

38 For these five villages some one hundred and fifty-five court rolls remain for this period. A detailed description of this survey appears in The Economic History Review, number 1, 1965, pp. 83-100, under the title "Social Structures in Five East Midland Villages: a study of the possibilities in the use of court roll data." 
tradesmen, and a fringe class. The three groups emerge more clearly in the rolls because each group is in its own fashion regional as well as local. Custom was a sufficient record for much of local life, and only infrequently do customs peek through the written records. But custom could not cover the change and mobility of regional life. Entered on the court rolls are the personal pledges that allowed this wider scope of life. Mobility of main villagers, mostly villeins for the villages under study here, grew from an economic framework on inter-commoning, open fields, contracts, debts, and multiple social ties. Mobility of tradesmen, and perhaps some officials, was the mobility of freemen and of an easily arranged movement of villeins. By means of a pledge, and a nominal fee, dozens of prominent villeins lived off their home village for periods of two or twenty years in order to exploit neighbouring opportunities. Mobility of fringe persons was that of a people of no real status; they probably remained on a desperate level where opportunities of seasonal employment, rules of gleaning or possibilities of acceptance by an affluent villein as pledge overshadowed the usual formalities of social, economic or legal status in the village. ${ }^{39}$

While various sorts of mobility provide valuable indices for the strength and flexibility of the total village life, these indices are still marginal. The heart of village life and organization lay in the main families. A simple behavioural analysis such as has been done thus far isolates these families in a manner hitherto impossible to studies based on a legal investigation of villeinage, or to economic studies based on unilateral obligations detailed in extents. In the total behavioural pattern of the court roll the dependence of villein upon his lord is only one of a score of vital relations in his life. Furthermore, this relation to the lord was formal and remote, in contrast with the daily dependence of wife, children, servants, pledged, wanderers, and so forth upon the main tenant himself. To note this is not to idealize the main villagers. If

39 For adaptation to demographic considerations, these varied opportunities of village life demand a much more intricate analysis than those studies largely derived from more static sources, such as the valuable works of J. C. Russell (British Medieval Population, Albuquerque, University of New Mexico Press, 1948), or E. A. Kosminsky (Studies in the Agrarian History of England in the thirteenth century, New York, 1956).

Certainly the nearly 5,000 identifiable persons milling about within the approximately twenty-five square miles of these villages over the first half of the fourteenth century challenges the social impressions of Eileen Power that an average villager might meet only one hundred to two hundred persons in his lifetime (Cambridge Medieval History, VII, p. 746)!

While the variety of life open to the villein does support a more optimistic view of the total possibilities for the villager, court roll evidence does also well illustrate many ways by which the villagers were "lined up" for land before the Black Death. See M. M. Postan, "Some Economic Evidence of Declining Population in the Later Middle Ages," Economic History Review, Second Series, II (1949-50), pp. 221.246. 
main tenants were indeed often 'villein aristocrats'40 vis-a-vis others, it must not be forgotten that well before the twentieth century the position of aristocrats could be unenviable. There is plenty of evidence to suggest that the larger village families were involved in social strife and indeed poverty in many ways.

The next step would seem to be the study of the group we have called main families. For some of these, over the two or three generations there are some 150 texts. Among the many facets of village life that will be able to be studied in detail from these documents are the following :

1. Domestic manufacture - especially the brewing of ale in the village economy

2. Servants - as a social class beneath the villeins

3. Intervillager and intervillage contracts, in particular as a debt structure

4. Sensitivity to libel and slander - perhaps the best measuring rod the relation between individual and group in the village

5. Criminal disturbances - above all the phenomena of mild punishments, apparently from the social care and responsibility assumed for delinquents

6. Non-conformity - the extraordinary spread of misdemeanours throughout the whole village population

7. Parental discipline colliding with courts

8. Village versus ecclesiastical courts - local parish clergy are called into court, call others into court, and call each other into court, with apparent canonical abandon. When there are references to ecclesiastical courts, there appears to be jealousy on the part of the local court, for the villager is fined again for having been fined in an ecclesiastical court.

Before closing I must quote from one text that I came across early in my studies; this text warmed my interest in the question of mobility, but may also serve to give you an acquaintance with the persons of the villagers such as $I$ have not been able to do in this paper : "It is complained in the Upwood court of 1302 that John Willem, John Ryngedale, William the servant of Robert Goodhosebond, John the Tailleur, Robert the son of John Oliver, Hugh Curteys, Thomas the ploughman, Robert the son of Thomas Manger, and two shepherds of the lord, all of Wistow, had come to Great Ravely to the wake of Simon

40 See B. H. Slicher Van Bath, The Agrarian History of Western Europe, A.D. $500-1850$, pp. $135-6$. 
of Sudbury (ad vigilandum corpus Simonis de Sutbiry per noctem); and when rolling home through Upwood village threw rocks at the villagers' houses and made such a hoot and holler (et redeundo iacuerunt lapideas ad hostia vicinorum et male se huerunt), so that the villagers of Upwood very properly raised the hue and cry on them."

I think they deserve at least one more hue and cry ! 